Rainbow, C. \& Mitson, G. W. (1953). J. gen. Microbiol. 9, 371-375.

\title{
Nutritional Requirements of Acetic Acid Bacteria
}

\author{
By C. RAINBOW and G. W. MITSON \\ Department of Applied Biochemistry, University of Birmingham
}

SUMMARY: Seven strains of acetic acid bacteria were separated into two welldefined groups on nutritional criteria. One group grew relatively poorly in media containing amino-acids and glucose, but grew well when lactate replaced glucose. In the presence of glucose and lactate, but not of glucose alone, ammonia was utilized as the sole source of nitrogen. With one exception, this group required no added growth factors for growth in a defined medium.

The second group grew well when glucose, but not lactate, was supplied as the chief source of carbon and/or energy. Casein acid hydrolysate was a suitable source of nitrogen, but ammonia, as a sole source of nitrogen, failed to support growth even when lactate was present, except to a limited extent when the growth period was prolonged to 7 days. All members of this group required added nicotinate, pantothenate and $p$-aminobenzoate.

The nutritional requirements of species of Acetobacter have as yet been little studied; this paper reports a study of the nutritional requirements of seven strains of these organisms.

\section{METHODS}

Test organisms and inocula. Seven organisms were used: (1) Acetobacter acidum-mucosum (NCTC 6429); (2) A. mobile (NCTC 6428); (3) A. suboxydans (NCTC 7069); (4) A. capsulatum (NCTC 4943); (5) A. gluconicum (NCTC 4739); (6) $A$. turbidans (NCTC 6249); (7) $A$. viscosum (NCTC 6426).

Cultures of each were maintained on malt agar slopes and transferred fortnightly or as required. Inocula were prepared by transferring a little of the surface growth from a slope to $6 \mathrm{ml}$. of appropriate basal medium and incubating at $28^{\circ}$ for $40-96 \mathrm{hr}$. The cells were then washed twice (centrifuge) with $6 \mathrm{ml}$. portions of sterile $0.85 \%$ saline and finally shaken to a homogeneous suspension in a further $6 \mathrm{ml}$. portion. One drop of this suspension was used to inoculate each test.

Basal media. (a) For organisms (1), (2), and (3); g./100 ml. final volume: glucose, 2.0; syrupy lactic acid (A.R.), 1.0; casein acid hydrolysate ("vitaminfree') (Allen and Hanbury), 0.6; $\left(\mathrm{NH}_{4}\right)_{2} \mathrm{SO}_{4}$ (A.R.), $0 \cdot 1 ; \mathrm{KH}_{2} \mathrm{PO}_{4}$ (A.R.), 0.3; $\mathrm{MgSO}_{4} .7 \mathrm{H}_{2} \mathrm{O}$ (A.R.), $0 \cdot 2$; in $\mu \mathrm{g}$. $100 \mathrm{ml}$. final volume: $\mathrm{D}$-biotin, 0.08 ; calcium D-pantothenate, 100; thiamine, 100; pyridoxin $\mathrm{HCl}, 100$; nicotinic acid, 100; riboflavin, 10; $p$-aminobenzoic acid $(p-\mathrm{AB}), 10$; trace element solution (Emery, McLeod \& Robinson, 1946), 0.05 ml. Adjustment to pH 5.8 was made with $\mathrm{KOH}$ solution.

(b) For organisms (4), (5), (6) and (7), as (a) above, but with lactic acid omitted and $1.0 \mathrm{mg}$. adenine $/ 100 \mathrm{ml}$. added.

Growth tests were carried out in flat-bottomed tubes $(16 \cdot 5-17 \cdot 2 \mathrm{~mm}$. internal diameter) containing $3 \mathrm{ml}$. double-strength medium $+3 \mathrm{ml}$. of solution of test 
substances previously adjusted to $\mathrm{pH} 5.8$ when necessary. The tubes and contents were covered with loosely fitting glass caps and sterilized by autoclaving momentarily to $15 \mathrm{lb}$./sq.in. After inoculation, the tubes were incubated in a vertical position in air at $28^{\circ}$. The amount of growth was determined turbidimetrically by direct reading of each tube in the Spekker absorptiometer (Northam \& Norris, 1951). Results are quoted as the average readings of duplicate tubes.

\section{RESULTS \\ Carbon and/or energy requirements}

For these tests, the concentration of casein acid hydrolysate in the basal medium was decreased to one-half (to minimize the amount of carbon in the medium available from this source), glucose and lactate were omitted and replaced by the following test substances $(10 \mathrm{mg} . / \mathrm{ml}$.): D-glucose, D-fructose, D-galactose, D-mannose, L-arabinose, D-ribose, D-xylose, lactose, maltose sucrose, D-mannitol, D-sorbitol; equimolar to glucose: erythritol, glycerol, acetate, citrate, fumarate, $a$-ketoglutarate, lactate, L-malate, succinate.

The results showed that for A. acidum-mucosum, A. mobile and A. suboxydans (the $A$. mobile group) lactate was the best source of carbon and/or energy. The sugars and sugar alcohols promoted relatively poor growth, or no growth above that obtained in the unsupplemented medium. The $A$. mobile group failed to grow appreciably on acids except that, after prolonged incubation, $A$. acidum-mucosum and, to a smaller extent, $A$. suboxydans grew on acetate, and $A$. mobile on succinate and malate. Glycerol was a good substrate for $A$. mobile and $A$. suboxydans after an initial lag.

The metabolism of lactate in the absence of glucose by organisms of the $\boldsymbol{A}$. mobile group involved an increase in $\mathrm{pH}$ to $7 \cdot 0-7 \cdot 6$ after 7 days. In contrast, glucose was metabolized by all the organisms examined (except $A$. acidummucosum) to acid end products ( $\mathrm{pH}$ values of $c .3 \cdot 0$ after 7 days), probably gluconic, 2-ketogluconic and 5-ketogluconic acids, which are known to be products of glucose oxidation by Acetobacter species.

$A$. capsulatum, A.gluconicum, A.turbidans and $A$. viscosum (the $A$. viscosum group) possessed points of resemblance among themselves, whilst differing from the $\boldsymbol{A}$. mobile group. These organisms failed to grow on lactate and other organic acids but grew well on glucose, mannitol and (except $A$. gluconicum), sorbitol, erythritol or glycerol. Fructose was a less effective substrate than glucose. A. capsulatum proved unique in growing well on maltose.

\section{Nitrogen requirements}

Casein acid hydrolysate and $\left(\mathrm{NH}_{4}\right)_{2} \mathrm{SO}_{4}$ were tested as sources of nitrogen for growth in basal media from which these substrates had been omitted. In view of the marked stimulation of the growth of three strains produced by lactate, a parallel series of tests was also carried out in media containing lactate.

The results showed that casein hydrolysate was a suitable source of nitrogen for all seven organisms. In the absence of lactate, ammonia, as a sole source 
of nitrogen, was not utilized for growth by the $A$. mobile group. However, when lactate was present ammonia was assimilated by these organisms and growth in the presence of casein hydrolysate was greatly stimulated.

By contrast, the $A$. viscosum group failed to grow, except to a limited extent after a prolonged period of incubation, when ammonia was provided as the sole source of nitrogen whether lactate was present or not. Furthermore, in a medium containing casein hydrolysate, growth was depressed by lactate, the effect being particularly marked with $\boldsymbol{A}$. capsulatum and $\boldsymbol{A}$. gluconicum.

\section{Requirements for added growth factors}

The tests with the $\boldsymbol{A}$. mobile group were carried out in a defined medium consisting of the basal medium from which all growth factors and casein hydrolysate were omitted and in which the concentration of $\left(\mathrm{NH}_{4}\right)_{2} \mathrm{SO}_{4}$ was $0.3 \mathrm{~g} .1100 \mathrm{ml}$. The $A$. viscosum group was tested in the appropriate basal medium from which all growth factors, except adenine, were omitted. The casein acid hydrolysate used in this medium was tested separately with suitable micro-organisms to demonstrate that it was substantially free from biotin, thiamine, pyridoxin and riboflavin; the present tests showed it to be free from $p$-AB, pantothenate and nicotinate. The seven organisms were tested in the presence and absence of all the growth factors and in the absence of each factor singly.

The results showed that $A$. acidum-mucosum and $A$. suboxydans required no added growth factors. $A$. mobile required only $p-\mathrm{AB}$, which it required also when L-glutamic acid replaced $\left(\mathrm{NH}_{4}\right)_{2} \mathrm{SO}_{4}$. Each organism of the $A$. viscosum group showed an absolute requirement for pantothenate and nicotinate; the requirement for $\boldsymbol{p}$-AB became less marked on prolonged incubation.

Adenine was included in the test medium for the $A$. viscosum group because separate tests (Table 1 ), carried out with the appropriate basal medium from which adenine and $\boldsymbol{p}$-AB were omitted, showed that adenine was stimulatory for $A$. gluconicum, especially during the early stages of incubation, even in the presence of $p$-AB. Under similar conditions, adenine was not stimulatory for the other organisms of the $A$. viscosum group. Adenine did not substitute for $p$-AB, or did so only partially after prolonged incubation, for the organisms of

Table 1. Adenine and $\mathrm{p}-A B$ as growth factors for acetic acid bacteria

Tests in basal medium less adenine and $p$-AB. Age of inocula, $45 \mathrm{hr}$., except $A$. gluconicum, $96 \mathrm{hr}$. Concentrations for tests : $p$-AB, $0 \cdot 1 \mu \mathrm{g} . / \mathrm{ml}$.; adenine, $10 \mu \mathrm{g} . / \mathrm{ml}$. Growth as Spekker readings.

\begin{tabular}{|c|c|c|c|c|c|}
\hline \multirow[t]{2}{*}{600} & \multirow[b]{2}{*}{$\begin{array}{l}\text { Incubation } \\
\text { time (hr.) }\end{array}$} & \multicolumn{4}{|c|}{ Growth in basal medium plus } \\
\hline & & $\begin{array}{l}\text { No } \\
\text { additions }\end{array}$ & $p-\mathbf{A B}$ & Adenine & $\begin{array}{l}p \text {-AB }+ \\
\text { adenine }\end{array}$ \\
\hline A. capsulatum & $\begin{array}{r}44 \\
117\end{array}$ & $\begin{array}{l}0.03 \\
0.03\end{array}$ & $\begin{array}{l}0 \cdot 71 \\
1 \cdot 03\end{array}$ & $\begin{array}{l}0 \cdot 05 \\
0 \cdot 22\end{array}$ & $\begin{array}{l}0.75 \\
1.07\end{array}$ \\
\hline A. gluconicum & $\begin{array}{r}72 \\
117\end{array}$ & $\begin{array}{l}0.03 \\
0 \cdot 03\end{array}$ & $\begin{array}{l}0.05 \\
0.51\end{array}$ & $\begin{array}{l}0 \cdot 11 \\
0.51\end{array}$ & $\begin{array}{l}0.26 \\
0.74\end{array}$ \\
\hline A. turbidans & $\begin{array}{l}44 \\
92\end{array}$ & $\begin{array}{l}0.05 \\
0 \cdot 17\end{array}$ & $\begin{array}{l}0 \cdot 35 \\
\mathbf{0} \cdot 72\end{array}$ & $\begin{array}{l}0 \cdot 17 \\
0 \cdot 35\end{array}$ & $\begin{array}{l}\mathbf{0 \cdot 3 7} \\
\mathbf{0 \cdot 7 3}\end{array}$ \\
\hline A. viscosum & $\begin{array}{r}44 \\
117\end{array}$ & $\begin{array}{l}0 \cdot 05 \\
0 \cdot 16\end{array}$ & $\begin{array}{l}0 \cdot 25 \\
0 \cdot 63\end{array}$ & $\begin{array}{l}0 \cdot 12 \\
0 \cdot 38\end{array}$ & $\begin{array}{l}0 \cdot 28 \\
0 \cdot 64\end{array}$ \\
\hline
\end{tabular}


this group, although it is known to do so for the growth of some organisms in media containing mixed amino acids (Lampen, Jones \& Roepke, 1949; Cutts \& Rainbow, 1950).

\section{Groroth of the A. mobile group on organic acids in defined medium}

Results have been presented which show the effect on the growth of the $A$. mobile group of $(a)$ organic acids in a medium containing carbon fragments supplied as acid hydrolysed casein; $(b)$ lactate in media containing glucose as a potential energy source. The capacity of organic acids to support the growth of the $\boldsymbol{A}$. mobile group was also tested in a defined medium containing ammonium salts as sole source of nitrogen, both in the presence and absence of glucose. The results (Table 2) showed that lactate was both a source of energy and of carbon fragments for $\boldsymbol{A}$. acidum-mucosum and $\boldsymbol{A}$. suboxydans, but that $A$. mobile required the presence of glucose for good growth on the lactate ammonia medium. When the incubation period was prolonged for more than $96 \mathrm{hr}$., A. suboxydans grew on succinate and (less well) on citrate and aconitate, provided glucose was also present. In these cases, where both glucose and organic acid were necessary, the latter may provide carbon fragments for biosynthesis, glucose providing the necessary energy. The results also showed that, when ammonium salts were the sole source of nitrogen, the $A$. mobile group failed to grow appreciably when glucose was the sole source of carbon and energy.

Table 2. Growth of the Acetobacter mobile group in defined medium

Series $A$ : in basal medium from which casein acid hydrolysate, glucose and lactate were omitted. Concentration of $\left(\mathrm{NH}_{4}\right)_{2} \mathrm{SO}_{4}$ increased to $0.25 \mathrm{~g} \cdot 1100 \mathrm{ml}$.

Series B: as series A, but containing $0.5 \%$ of glucose in the medium.

Concentrations of test substrates : glucose, $10 \mathrm{mg}$. $/ \mathrm{ml}$., organic acids equimolar to glucose. Growth recorded as Spekker readings after 7 days incubation.

\begin{tabular}{|c|c|c|c|c|c|c|}
\hline \multirow[b]{2}{*}{ Substrate } & \multicolumn{3}{|c|}{ Series A } & \multicolumn{3}{|c|}{ Series B } \\
\hline & $\begin{array}{l}\text { A. acidum } \\
\text {-mucosum }\end{array}$ & A. mobile & $\begin{array}{l}\text { A. sub- } \\
\text { oxydans }\end{array}$ & $\begin{array}{l}\text { A. acidum } \\
\text {-mucosum }\end{array}$ & A. mobile & $\begin{array}{l}\text { A. sub- } \\
\text { oxydans }\end{array}$ \\
\hline None & 0.01 & 0.01 & 0.01 & 0.03 & 0.05 & 0.03 \\
\hline Glucose & 0.08 & 0.04 & 0.05 & - & - & - \\
\hline Acetate & 0.01 & 0.02 & 0.01 & 0.03 & $0 \cdot 10$ & 0.09 \\
\hline Aconitate & 0.02 & 0.04 & 0.09 & 0.06 & $0 \cdot 11$ & 0.24 \\
\hline Citrate & 0.01 & 0.01 & $0 \cdot 11$ & 0.03 & 0.07 & 0.45 \\
\hline Fumarate & 0.03 & 0.02 & 0.02 & 0.04 & 0.08 & 0.07 \\
\hline$\alpha$-Ketoglutarate & 0.06 & 0.02 & 0.07 & 0.04 & $0 \cdot 10$ & $0 \cdot 11$ \\
\hline Lactate & $1 \cdot 03$ & $0 \cdot 17$ & 0.84 & 0.98 & $0 \cdot 89$ & $1 \cdot 20$ \\
\hline L-Malate & 0.04 & 0.03 & 0.03 & 0.05 & $0 \cdot 12$ & $0 \cdot 12$ \\
\hline Succinate & 0.04 & 0.02 & 0.02 & 0.06 & 0.11 & 0.61 \\
\hline
\end{tabular}

\section{DISCUSSION}

The organisms studied fall into two groups, each with a distinct nutritional pattern. The ability to utilize ammonia as sole source of nitrogen is of interest in connexion with the proposal of this criterion for the identification of acetic acid bacteria (Vaughn, 1942). Of the organisms discussed in this paper, the $A$. mobile group possessed this ability only when lactate was present. The composition of the medium for identification tests based on the criterion suggested by Vaughn is therefore important. 
The periods of induction necessary before the metabolism of acetate (by $A$. acidum-mucosum and $A$. suboxydans) malate and succinate (by $A$. mobile) and glycerol (by $\boldsymbol{A}$. mobile and $\boldsymbol{A}$. suboxydans) suggests that adaptive enzymes are involved. It is noteworthy that the utilization of acetate for growth by A. acidum-mucosum and $\boldsymbol{A}$. suboxydans only took place in the presence of amino-acids.

Foda \& Vaughn (1953) found that $A$. melanogenum, $A$. oxydans and $A$.rancens require added $p-\mathbf{A B}$, nicotinate, pantothenate and certain amino-acids. The resemblance between these results and our own suggests that this particular pattern of nutritional requirements is common to all the organisms concerned and may be, as Foda \& Vaughn suggested, of taxonomic value.

Although $A$. gluconicum grew well in $48 \mathrm{hr}$. on malt agar slants, it grew considerably slower on the basal medium than any other strain used in this work. It seems likely, therefore, that the basal medium lacked a factor or factors stimulatory to this organism.

\section{REFERENCES}

Cutrs, N. S. \& Rarnbow, C. (1950). Studies of a yeast exacting towards $p$-aminobenzoic acid. J. gen. Microbiol. 4, 150.

Emery, W. B., McLeod, N. \& Robinson, F. A. (1946). Comparative microbiological assay of members of the vitamin $B$ complex in yeast and liver extracts. Biochem. J. 40, 426.

FODA, I. O. \& VAUGH, R. H. (1953). The nutritional requirements of Acetobacter melanogenum and related species. J. Bact. 65, 79.

LAMPren, J. O., Jones, M. J. \& RoEPKe, R. R. (1949). Mutant strains of Escherichia coli unable to synthesize $p$-aminobenzoic acid. J. biol. Chem. 180, 428.

Northam, B. E. \& Norris, F. W. (1951). Growth requirements of Schizosaccharomyces octosporus, a yeast exacting towards adenine. J. gen. Microbiol. 5, 502.

Vaughn, R. H. (1942). The acetic acid bacteria. Wallerstein Labs. Commun. 5, 5.

(Received 21 April 1953) 